\title{
ANALISIS PENGARUH PIUTANG DAN PENJUALAN KREDIT TERHADAP PROFITABILITAS PERUSAHAAN TAHUN 2016-2018 (STUDI KASUS CV DAVIN JAYA KARIMUN)
}

\author{
Yusmalina $^{1}$, Sinta Novita Sari ${ }^{2}$, Fauzan Haqiqi ${ }^{3}$, Verawaty Tambunan \\ Program Studi Akuntansi, Fakultas Ilmu Sosial dan Humaniora, Universitas Karimun, Provinsi \\ Kepulauan Riau, Indonesia \\ Email : yusmalina8484@gmail.com ${ }^{1}$, sintanovitasari953@gmail.com², fauzanhaqiqi1986@gmail.com³
}

\begin{abstract}
Abstrak
CV. Davin Jaya merupakan perusahaan dagang yang bergerak di bidang distribusi makanan dan minuman serta kebutuhan pokok rumah tangga. Tujuan dari penelitian ini adalah untuk mengetahui pengaruh baik secara simultan maupun parsial antara perputaran piutang dan penjualan kredit terhadap profitabilitas CV Davin Jaya Karimun, yang diukur dari variabel-variabel perputuran piutang dan penjualan kredit. Penelitian ini menggunakan metode kualitatif dengan menggunakan data sekunder. Populasi dalam penelitian ini adalah laporan keuangan CV Davin Jaya Karimun dan sebanyak 36 sampel penelitian. Adapun teknik analisis data yang digunakan adalah statistik deskripstif dan regresi linear berganda dengan menggunakan metode
\end{abstract}

Kata kunci: Perputaran Piutang, Penjualan Kredit, Profitabilitas

\section{PENDAHULUAN}

Dalam usaha memperoleh keuntungan, perusahan dihadapkan pada masalah penagihan piutang. Karena pada dasarnya penjualan secara kredit pasti akan ada dihadapkan dengan pelanggan yang tidak sanggup membayar atau mempunyai keterlambatan dalam pelunasan piutang. Modal yang ditanankan pada perusahaan akan diinvestasikan dalam berbagai macam aktiva yang dibutuhkan perusahaan CV Davin Jaya.

Modal dalam perusahaan juga dapat di investasikan dalam piutang dan return (pengembalian) karena berpengaruh terhadap laporan keuangan perusahaan. Masalah piutang ini menjadi begitu penting dalam kaitannya dengan perusahaan CV Davin Jaya manakala harus menentukan berapa jumlah piutang yang optimal. Disamping itu piutang juga harus dikelola dengan efisien yang menyangkut tentang laba atau tambahan laba yang diperoleh dengan perubahan kebijakan penjualan dengan beban yang timbul karena adanya piutang.

Saldo piutang rata-rata adalah saldo rata-rata piutang bersih (setelah dikurangi piutang tak tertagih) ditambah saldo akhir dibagi dua. Pihak manajemen harus pandai mengelola piutang sehingga perputaran nya cepat dan pada akhirnya dapat meningkatkan laba dan kas yang baik.

Rasio piutang usaha ini menggambarkan posisi piutang usaha secara kredit serta menggambarkan kualitas dan kesuksesan perusahaan dalam menagih piutangnya. Semakin tinggi perputaran piutang usaha menggambarkan kualitas dan kesuksesan seorang pekerja dalam menagih piutang serta menunjukkan modal kerja yang disimpan 
dalam piutang usaha rendah. Akan tetapi, jika rasio piutang usaha terlalu tinggi akan mengakibatkan ketidaksukaan anggota karena kebijakan kredit yang terlalu ketat. Sebaliknya jika piutang usaha rendah berarti piutang tidak berjalan lancar secara efektif.

Dalam dunia penjualan, kita sering mendengar istilah penjualan secara kredit, apalagi bagi seorang tenaga penjualan atau sales pasti akan sering mendengar istilah tersebut.Tujuan perusahaan melakukan penjualan kredit ialah untuk meningkatkan penjualan,meningkatkan laba, dan menghadapi pesaing.

\section{TINJAUAN PUSTAKA}

\section{Teori Keagenan}

Teori keagenan mendeskripsikan hubungan antara pemegang saham (share holders) sebagai prinsipal dan manajemen sebagai agen. Manajemen merupakan pihak yang di kontrak oleh pemegang saham untuk bekerja demi kepentingan pemegang saham. Karena mereka dipilih, maka pihak manajemen harus mempertanggungjawabkan semua pekerjaannya kepada pemegang saham. Jensen dan Meckling (1976) menjelaskan hubungan keagenan sebagai "agency relationship as a contract under which one or more person (the agent) to perform some service on their behalf which involves delegating some decision making authority to the agent".

\section{Piutang}

Menurut James C. Van Home dan John M. Wachowicsz,Jr (1997:258): “ Piutang adalah jumlah uang dipinjam dari perusahaan oleh pelanggam yang telah membeli barang atau jasa secara kredit".

Selanjutnya pengertian piutang menurut Lukman Syamsudin ( 2007:225) adalah “ piutang adalah tagihan yang timbul karena adanya transaksi secara kredit oleh perusahaan kepada langganannya".

Dari Donald E.Kleso (200:34634) menyebutkan bahwa piutang adalah klaim,uang barang, atau jasa kepada pelanggan atau pihak-pihak lainnya. Piutang dikelompokkan kedalam hutang lancar atau tidak lancar.

\section{Penjualan Kredit}

Penjualan kredit yaitu penjualan yang pembayarannya dilakukan setelah penyerahan barang denganjangka waktu yang telah disepakati oleh kedua belah pihak. Penjualan kredit dilaksanakan oleh perusahaan dengan cara mengirimkan barang sesuai order yang diterima dari pembeli dan untuk jangka waktu perusahaan mempunyai tagihan kepada pembeli tersebut.

\section{Profitabilitas}

Profitabilitas adalah kemampuan perusahaan memperoleh laba dalam hubunganya dengan penjualan, total aktiva maupun modal sendiri. Bagi investor jangka panjang akan sangat berkepentingan dengan analisis profitabilitas ini misalnya bagi pemegang saham akan melihat keuntungan yang benar-benar akan diterima dalam bentuk deviden (Sartono, 2008). Profitabilitas juga merupakan salah satu 
pengukuran kinerja perusahaan yang dapat diukur dalam rasio untuk menggambarkan kemampuan perusahaan dalam menghasilkan laba. Semua perusahaan selalu berusaha untuk meningkatkan profitabilitasnya. Jika perusahaan berhasil meningkatkan profitabilitasnya, maka dapat dikatakan bahwa perusahaan tersebut mampu mengelola sumber daya yang dimiliki nya secara efektif dan efisien sehingga mampu menghasilkan laba yang tinggi Sebaliknya, sebuah perusahaan memiliki profitabilitas rendah menunjukkan bahwa perusahaan tersebut tidak mampu mengelola sumber daya yang dimilikinya dengan baik, sehingga tidak mampu menghasilkan laba tinggi. Penggunaan rasio profitabilitas dapat dilakukan dengan menggunakan perbandingan antara beberapa komponen yang ada dilaporan keuangan, terutama laporan keuangan neraca dan loparan laba rugi.

\section{Gambar 3.2}

\section{Kerangka Konseptual}

\begin{tabular}{|c|c|c|}
\hline $\begin{array}{l}\text { Penjualan Kredit } \\
\left(\mathbf{X}_{2}\right): \\
\text { - Kredit Macet } \\
\text { - Kredit Lancar }\end{array}$ & $r_{x 2 y}$ & $\begin{array}{l}\text { Profitabilitas }(\mathbf{Y}) \\
\text { - } \text { Kemampuan } \\
\text { perusahaan CV } \\
\text { Davin Jaya } \\
\text { memperoleh } \\
\text { laba/keuntungan } \\
\text { selama periode } \\
\text { tertentu dimana } \\
\text { dalam penelitian } \\
\text { ini profitabilitas } \\
\text { dihitung dengan } \\
\text { menggunakan } \\
\text { Gross Profit } \\
\text { Margin. }\end{array}$ \\
\hline
\end{tabular}

Keterangan:

$\mathrm{X}_{1} \quad$ : Piutang

$\mathrm{X}_{2} \quad$ : Penjualan Kredit

Y : Profitabilitas

$\longrightarrow \quad$ : Pengaruh variabel bebas terhadap variabel terikat secara individu

$\rightarrow \quad$ : Pengaruh variabel bebas terhadap variabel terikat secara bersama-sama

$\mathrm{r}_{\mathrm{x} 1 \mathrm{y}} \quad$ : Pengaruh piutang terhadap profitabilitas Perusahaan

$\mathrm{r}_{\mathrm{x} 2 \mathrm{y}} \quad$ :Pengaruh Penjualan Kredit terhadap Profitabilitas Perusahaan 
$\mathrm{R}_{\mathrm{xy}} \quad$ : Pengaruh piutang dan penjualan kredit terhadap profitabilitas perusahaan.

\section{METODE PENELITIAN}

Penelitian ini berusaha untuk mengungkapkan gejala-gejala serta pengaruh antar ubahan yang hasil analisisnya disajikan dalam bentuk deskripsi dengan menggunakan angka-angka statistik. Oleh karena itu pendekatan yang dipergunakan adalah pendekatan kuantitatif. Sesuai pendapat Sugiyono (2008:14) bahwa penelitian kuantitatif adalah penelitian yang berlandaskan pada filsafat positifisme, digunakan untuk meneliti populasi atau sampel tertentu, pengumpulan data menggunakan instrumen penelitian terhadap karyawan atas pengaruh perputaran piutang dan penjualan kredit terhadap profitabilitas perusahaan, analisis data bersifat kuantitatif atau statistik yang disajikan dengan angka dan bertujuan untuk menguji hipotesis yang telah ditetapkan.

Adapun metode penelitian yang digunakan adalah dokumentasi dan informasi di kumpulkan dengan menggunakan wawancara kepada karyawan.

\section{Populasi}

Berdasarkan pengertian diatas, maka populasi dalam penelitian ini adalah keseluruhan karyawan CV. Davin Jaya Karimun, Kecamatan Karimun, Kabupaten Karimun yang berjumlah 32 orang.

\section{HASIL DAN PEMBAHASAN}

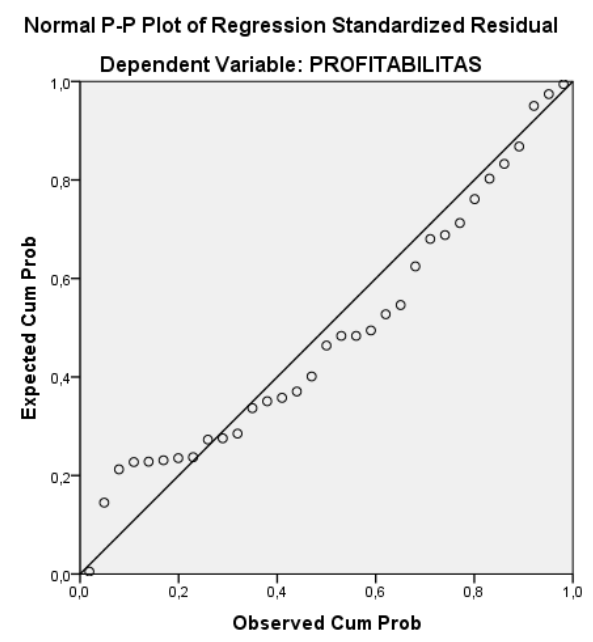

Berdasarkan hasil pengolahan data maka didapatkan hasil bahwa semua data berdistribusi secara normal dan tidak terjadi penyimpangan, sehingga data yang dikumpulkan dapat diproses dengan metode-metode selanjutnya. Hal ini dapat dibuktikan dengan memperhatikan sebaran data yang menyebar disekitar garis diagonal pada "Normal P-Plot of Regresion Standardized Residual" sesuai gambar diatas, 
sehingga dapat dikatakan bahwa model regresi dalam penelitian ini berdistribusi normal.

\section{Uji Multikolinieritas}

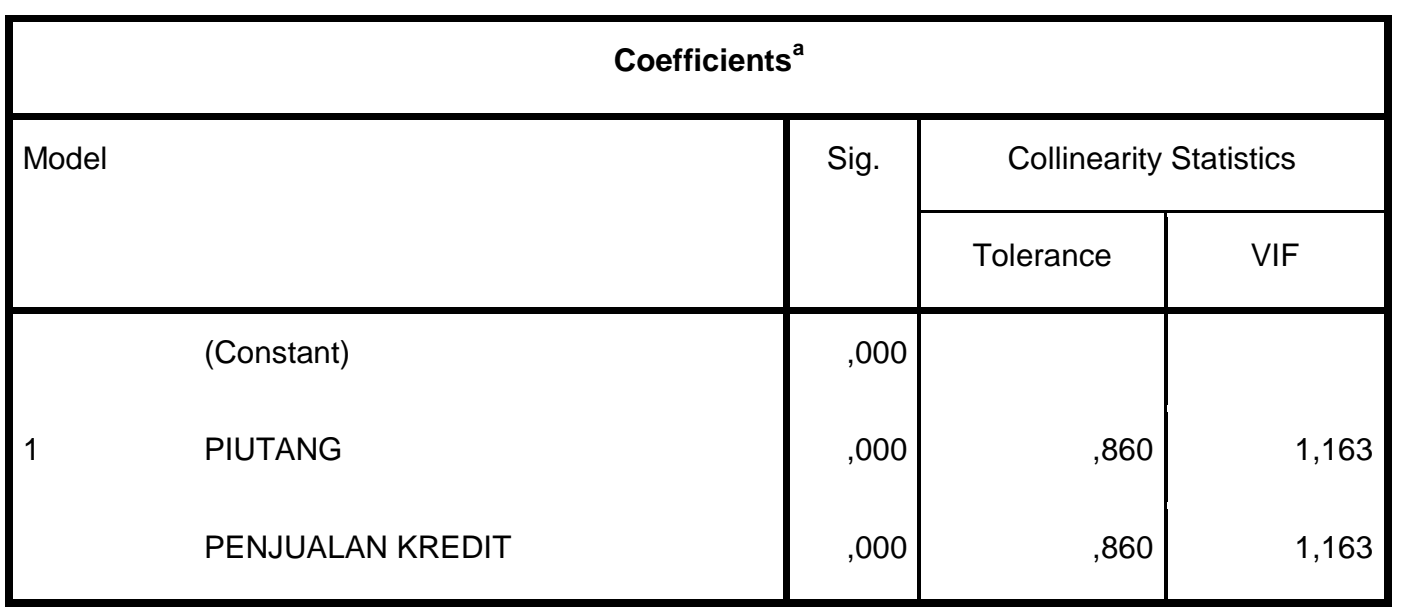

Dari tabel diatas terlihat bahwa nilai VIF untuk masing-masing variabel independent dalam persamaan ini memiliki nilai $<10$ dan nilai tolerance $>10$, maka semua variabel dinyatakan tidak terkena masalah multikolinearitas. Hal ini bisa disimpulkan bahwa semua variabel independen tidak mempunyai korelasi yang sangat kuat.

1. Nilai tolerance variabel piutang sebesar 0,860 dan VIF sebesar 1,163

2. Nilai tolerance variabel penjualan kredit 0.515 dan VIF sebesar 1.943.

Nilai-nilai yang di dapat dari perhitungan adalah sesuai dengan ketetapan nilai VIF dan tolerance, sehingga dapat disimpulkan bahwa dalam model regresi tersebut tidak menunjukkan adanya gejala multikolinieritas. Dari tabel 4.3 maka dapat diketahui bahwa nilai toleransi dan VIF volume piutang 0,860 dan VIF 1.163. Penjualan Kredit sebesar 0,860 dan VIF 1.163. Hasil tersebut menunjukkan nilai toleransi lebih dari 0,10 dan nilai VIF kurang dari 10, maka variabel penelitian dianggap bebas dari gejala multikolineritas. Sebagimana hasil analisis diatas, dapat dinyatakan bahwa variabel dalam penelitian ini dapat dinyatakan tidak mengalami gangguan multikolinearitas.

\section{Hasil Uji Heteroskedastisitas}

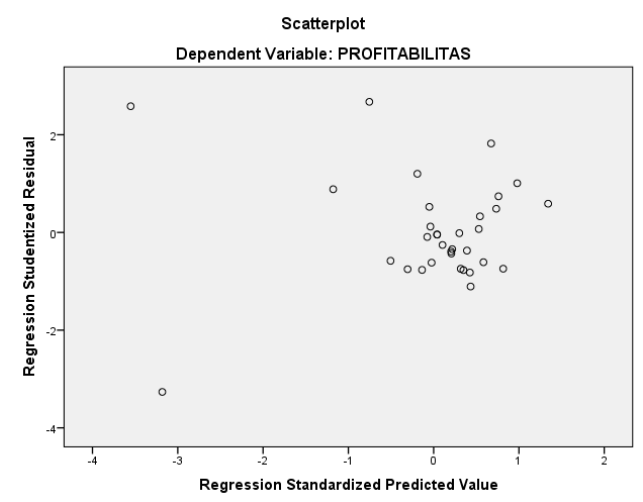


Berdasarkan gambar diatas grafik scatterplot diatas terlihat bahwa titik-titik menyebar secara acak hal ini disimpulkan bahwa tidak terjadi heteroskedastisitas pada model regresi ini. Salah satu cara untuk mendeteksi heteroskedastisitas adalah dengan melihat grafik scatter plot antara nilai prediksi variabel terikat (ZPRED) dan nilai residualnya (SRESID). Jika titik-titik membentuk pola tertentu yang teratur seperti gelombang besar melebar, kemudian menyempit maka telah terjadi heteroskedastisitas.

Jika titik-titik menyebar diatas dan dibawah angka 0 pada sumbu $\mathrm{Y}$ tanpa membentuk pola tertentu,maka tidak terjadi Heteroskedastisitas.

\section{Uji Regresi Liniear Berganda}

\section{Coefficients $^{\mathrm{a}}$}

\begin{tabular}{|c|c|c|c|c|c|}
\hline \multirow{2}{*}{\multicolumn{2}{|c|}{ Model }} & \multicolumn{2}{|c|}{ Unstandardized Coefficients } & \multirow{2}{*}{$\begin{array}{c}\text { Standardized } \\
\text { Coefficients } \\
\text { Beta }\end{array}$} & \multirow[t]{2}{*}{$\mathrm{t}$} \\
\hline & & B & Std. Error & & \\
\hline \multirow{3}{*}{1} & (Constant) & 1,453 & ,004 & & 397,341 \\
\hline & PIUTANG & $1,616 \mathrm{E}-008$ &, 000 & 1,064 & 710,085 \\
\hline & PENJUALAN KREDIT & $-2,349 \mathrm{E}-008$ & ,000 &,- 561 & $-374,321$ \\
\hline
\end{tabular}

Sumber : output SPSS versi 20

Hasil pengolahan dengan menggunakan SPSS 20 menunjukkan persamaan regresi berganda sebagai berikut :

$\mathrm{Y}=\mathrm{a}+\mathrm{b}_{1} \mathrm{X}_{1}+\mathrm{b}_{2} \mathrm{X}_{2}$

$\mathrm{Y}=1,453+1,616 \mathrm{E}-008 \mathrm{X}_{1}+(-2,349 \mathrm{E}-008) \mathrm{X}_{2}$

$\mathrm{Y}=1,453+1,616 \mathrm{EX}_{1}-2,349-008 \mathrm{X}_{2}$

Persamaaan regresi diatas dapat dijelaskan sebagai berikut:

1. Konstan sebesar 1,453 menyatakan bahwa jika tidak ada nilai Trust maka nilai partisipasinya sebesar Rp 1,453.

2. Koefisien regresi variable piutang $\left(\mathrm{X}_{1}\right)$ sebesar $1.616-008=0,816$ menyatakan jika variable independen lain nilainya tetap dan piutang mengalami kenaikan 1\% maka Profitabilitas (Y) akan mengalami sebesar Rp 0,816 .

3. Koefisien bernilai positif artinya terjadi hubungan positif antara piutang dengan profitabilitas.

4. Koefisien regresi variable Beban ( $\mathrm{x}_{2}$ ) sebesar -2,349E-008 menyatakan jika variabel independen lain nilainya tetap dan penjualan kredit mengalami penurunan $1 \%$ maka profitabilitas (Y) akan mengalami penurunan sebesar 2,349E-008. Koefisien bernilai negatif artinya terjad hubungan yang negatif antara penjualan kredit dengan probitabilitas, semakin naik penjualan kredit maka semakin turun profitabilitas. 
Uji Analisa Koefesien Determinan $\mathbf{R}^{2}$ (R Square)

Uji Analisa Determinasi

Model Summary

\begin{tabular}{|l|r|r|r|r|r|}
\hline Model & $\mathrm{R}$ & $\mathrm{R}$ Square & \multicolumn{1}{|c|}{$\begin{array}{l}\text { Adjusted } \mathrm{R} \\
\text { Square }\end{array}$} & $\begin{array}{l}\text { Std. Error of the } \\
\text { Estimate }\end{array}$ & Durbin-Watson \\
\hline 1 & $1,000^{\mathrm{a}}$ & 1,000 & 1,000 &, 00033 & 1,721 \\
\hline
\end{tabular}

a. Predictors: (Constant), PENJUALAN KREDIT, PIUTANG

b. Dependent Variable: PROFITABILITAS

Berdasarkan tabel diatas diperoleh angka $\mathrm{R}^{2}$ ( $\mathrm{R}$ Square) sebesar 1,000 atau $(100 \%)$. Hal ini menunjukkan bahwa persentase sumbangan pengaruh variabel independen ( piutang dan penjualan kredit) terhadap variabel dependen (profitabilitas) sebesar $100 \%$ Atau variasi variabel independen yang digunakan dalam model (piutang dan penjualan kredit) mampu menjelaskan sebesar $100 \%$ variasi variabel dependen (profitabilitas).

\section{Uji Regresi Secara Simultan (Uji F)}

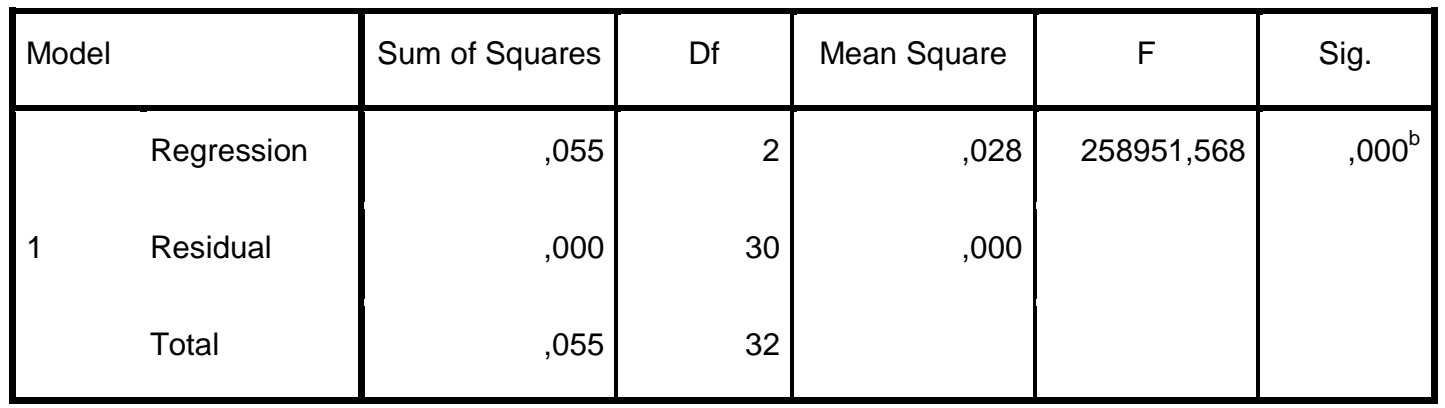
a. Dependent Variable: PROFITABILITAS
b. Predictors: (Constant), PENJUALAN KREDIT, PIUTANG 


\section{Uji Regresi Secara Parsial (Uji t)}

\begin{tabular}{|c|c|c|c|c|c|c|c|c|}
\hline \multirow[t]{2}{*}{ Mode } & & \multicolumn{2}{|c|}{$\begin{array}{l}\text { Unstandardized } \\
\text { Coefficients }\end{array}$} & \multirow{2}{*}{$\begin{array}{c}\begin{array}{c}\text { Standardize } \\
d \\
\text { Coefficients }\end{array} \\
\text { Beta }\end{array}$} & \multirow[t]{2}{*}{ t } & \multirow[t]{2}{*}{ Sig. } & \multicolumn{2}{|c|}{$\begin{array}{l}\text { Collinearity } \\
\text { Statistics }\end{array}$} \\
\hline & & $B$ & $\begin{array}{l}\text { Std. } \\
\text { Error }\end{array}$ & & & & Tolerance & VIF \\
\hline & (Constant & 1,453 & 004 & & 397,341 & , 000 & & \\
\hline & PIUTANG & $1.62 \mathrm{E}-008$ & ,000 & 1,064 & 710,085 & ,000 & ,860 & $\begin{array}{l}1,1 \\
63\end{array}$ \\
\hline 1 & $\begin{array}{l}\text { PENJUAL } \\
\text { AN } \\
\text { KREDIT }\end{array}$ & $-2.35 \mathrm{E}-008$ &, 000 &,- 561 & $-374,321$ &, 000 & 860 & $\begin{array}{l}1,1 \\
63\end{array}$ \\
\hline
\end{tabular}

\section{Pembahasan Hasil Analisa Data}

a. Pengaruh variabel piutang (X1) dan penjualan kredit (X2) terhadap profitabilitas (Y) CV Davin Jaya Karimun.

Berdasarkan tabel diperoleh nilai $\mathrm{F}_{\text {hitung }}$ 258951,568 dengan nilai sig 0,000. Hal ini menujukkan nilai sig lebih kecil dari 0,05. Dengan demikian $\mathrm{H}_{0}$ ditolak dan $\mathrm{H}_{\mathrm{a}}$ diterima. Artinya piutang dan penjualan kredit mempunyai pengaruh yang signifikan terhadap profitabilitas perusahaan.

b. Pengaruh variabel piutang (X1) terhadap Profitabilitas (Y) CV Davin Jaya Karimun.

Berdasarkan tabel dapat diperoleh nilai $\mathrm{t}$ hitung sebesar 710,085 dengan nilai sig 0,000. Hal ini menunjukkan bahwa nilai $\mathrm{t}_{\text {hitung }}$ lebih kecil dari nilai $\mathrm{t}$ tabel 1,692 dan nilai sig lebih kecil dari 0,05. Demikian $\mathrm{H}_{0}$ ditolak dan $\mathrm{H}_{\mathrm{a}}$ diterima. Artinya variabel piutang mempunyai pengaruh yang signifikan terhadap profitabilitas perusahaan.

c. Pengaruh variabel penjualan kredit (X2) terhadap Profitabilitas (Y) CV Davin Jaya Karimun.

Berdasarkan tabel dapat diperoleh nilai $t$ hitung sebesar dengan nilai sig 0,000. Hal ini menunjukkan bahwa nilai $t$ hitung lebih kecil dari nilai $\mathrm{t}_{\text {tabel }} 1,692$ dan nilai sig lebih kecil dari 0,05. Demikian $\mathrm{H}_{0}$ ditolak dan $\mathrm{H}_{\mathrm{a}}$ diterima. Artinya variabel penjualan kredit mempunyai pengaruh yang signifikan terhadap profitabilitas perusahaan.

\section{KESIMPULAN}

Berdasarkan hasil analisis, maka kesimpulan yang diambil dari penelitian ini sebagai berikut :

1. Pengaruh variabel Piutang (X1) dan Penjualan Kredit (X2) terhadap profitabilitas (Y). 
Berdasarkan tabel diperoleh nilai $\mathrm{F}$ hitung 258951,568 dengan nilai sig sebesar 0,000. Hal ini menunjukkan nilai sig lebih kecil dari 0,05. Dengan demikian $\mathrm{H}_{0}$ ditolak dan $\mathrm{H}_{\mathrm{a}}$ diterima. Artinya Piutang dan Penjualan Kredit berpengaruh signifikan terhadap profitabilitas.

2. Pengaruh Variabel Piutang (X1) terhadap Profitabilitas (Y) Cv Davin Jaya Karimun.

3. Berdasarkan tabel diperoleh nilai $t_{\text {hitung }} 710,085$ dengan nilai sig sebesar 0,000 . Hal ini menunjukkan nilai $t_{\text {hitung }}$ lebih kecil dari $t_{\text {tabel }}$ 1,692 dan nilai sig lebih kecil dari 0,05. Dengan demikian $\mathrm{H}_{0}$ ditolak dan $\mathrm{H}_{\mathrm{a}}$ diterima. Artinya piutang mempunyai pengaruh signifikan terhadap profitabilitas.

4. Pengaruh variabel penjualan kredit (X2) terhadap profitabilitas CV Davin Jaya Karimun.

5. Berdasarkan tabel diperoleh nilai $t_{\text {hitung }}-374.321$ dengan nilai sig sebesar 0,000 . Hal ini menunjukkan nilai $t_{\text {hitung }}$ lebih kecil dari $t_{\text {tabel }} 1,692$ dan nilai sig lebih kecil dari 0,05.Dengan demikian $\mathrm{H}_{0}$ ditolak dan $\mathrm{H}_{\mathrm{a}}$ diterima. Artinya Piutang mempunyai pengaruh signifikan terhadap profitabilitas. 


\section{DAFTAR PUSTAKA}

Alurkaniawati, et.al. (2016). Pengantar Akuntansi I. Medan : Madenatara

Arikunto. Prosedur Penelitian Suatu Pendekatan Praktek, Jakarta : Rineke Cipta, 2022 BPEE, Yoyyakarta. 2003.

Bringham, et.al. (2004). Dasar-Dasar Manajemen Keuangan. Jakarta : Salemba Empat

Copeland E Thomas, Fred J Weston. (1995). Manajemen Keuangan. Edisi Kesembilan. Jakarta : Binarupa Aksara

Elliott, Hongren, Sundem. (1998). Pengantar Akuntansi Keuangan. Jakarta

Erlangga Gitosundarmo, Indriyo dan Basri. (1992). Manajemen Keuangan Edisi Kedua. Yogyakarta : BPEE Yogyakarta

Gitosudarmo Indriyo dan Basri. (2002). Manajemen Keuangan Edisi Ketiga. Yogyakarta : BPEE Yogyakarta

Harahap, Sofyan Safri. (2011). Analisis Krisis Atas Laporan Keuangan, Edisi 1-10 Cetakan Kesepuluh Jakarta : rajawali pers

Iqbal, Hasan. (2001). Pokok Materi Statistik I, Edisi Kedua. Jakarta : Bumi Aksara

Lawrence, J Gitmen. (1992). Basic Manajerial Finance. Third Edition. AddisonWesley.

Riyanto, Bambang. (1995). Dasar-Dasar Pembelanjaan Perusahaan, Edisi Keempat. Yogyakarta : Yayasan Penerbit Universitas Gajah Mada.

Riyanto, Bambang.(1997). Dasar-Dasar Perkreditan, Edisi Keempat Yogyakarta : BPEE. Yogyakarta

Munawir, S, Analisis Laporan Keuangan. Edisi Keempat, Yogyakarta : Liberty

Syamsuddin, Lukman. (2002). Manajemen Keuangan Perusahaan, Jakarta : PT. Raja Grafindo Persada.

Suyatno, Thomas. (1993). Dasar-Dasar Perkreditan, Edisi Kedua, Jakarta : PT. Gramedia Pustaka Utama.

Sundjaya S, Ridwan, Inge Barlian. (2003). Manajemen Keuangan I, Edisi Kelima, Jakarta : Literata Jendela Dunia Ilmu.

Van Horne, James C. Fundamental's Of Financial Management. Eight Edition Engle Wood Clifts NJ : Prentice-Hall Inc.

Van Horne, James C, John M Wachowics. (1997). Prinsip-Prinsip Manajemen Keuangan, Edisi Kesembilan : Salemba Empat. 